\title{
Implementation of Inclusive Education for Children with Special Needs in Regular Schools in North Sumatera Province
}

\author{
Mhd Iqbal*, Agus Sukristyanto, Arif Darmawan \\ Adminstrative Science, Universitas 17 Agustus 1945 Surabaya, Surabaya, Indonesia \\ Email address: \\ iqbalmhd944@gmail.com (M. Iqbal), agussukris@untag-sby.ac.id (A. Sukristyanto), arif@untag-sby.ac.id (A. Darmawan) \\ ${ }^{*}$ Corresponding author
}

To cite this article:

Mhd Iqbal, Agus Sukristyanto, Arif Darmawan. Implementation of Inclusive Education for Children with Special Needs in Regular Schools in North Sumatera Province. Journal of Public Policy and Administration. Vol. 5, No. 1, 2021, pp. 1-7. doi: 10.11648/j.jppa.20210501.11

Received: January 15, 2021; Accepted: January 26, 2021; Published: February 9, 2021

\begin{abstract}
Research related to inclusive education in regular schools is still minimal. This is a great opportunity for researchers to explore more deeply related to policy implementation on the object of study. There are indications that inclusive education in North Sumatra is not running optimally, therefore this research is increasingly interesting how the massive launching carried out in 2015 had an insignificant impact on the implementation of inclusive education. To analyze the mechanism for providing education for children with special needs in regular schools that provide inclusive education in North Sumatra. To analyze the role of SLB support as a companion to regular schools in providing inclusive education in North Sumatra Province. This type of research is descriptive. This study uses a qualitative approach that aims to describe and analyze phenomena related to public services in the implementation of inclusive education at regular schools in North Sumatra Province. The results of this research see that the decree issued as a form of responsiveness to Permendiknas no. 70 of 2009 is indeed a necessity, but the seriousness of the provincial government regarding a regulation is of course the issuance of derivative regulations or a response to regulations issued nationally related to inclusive education. This is what is not seen in North Sumatra Province. After the big declaration of inclusive education in 2015, there has not been any binding regulation on inclusive education in North Sumatra. However, in relation to inclusive education, the three schools designated as providers of Inclusive education for SMA / Ma level still run the rules and accept ABK in schools. The conclusion in this study is that the role of SLB organizers who accompany regular schools in providing inclusive education in North Sumatra Province has never been carried out. This is because communication between the North Sumatra Education Office, regular schools that provide inclusive education and special schools as support staff has never been carried out. Inclusive education services in regular schools in North Sumatra Province which implement the policy of inclusive education, reflected in Permendiknas No. 70 of 2009, are not running well. This can be seen from regulations at the provincial and district levels in North Sumatra which never existed as a translation of Permendikbud No. 70 of 2009 concerning Inclusive Education.
\end{abstract}

Keywords: Inclusive Education, North Sumatera Education, ABK in Regular School

\section{Introduction}

In Indonesia, the implementation of inclusive education has actually been initiated since 1986 . The First name is not inclusive education but integrated education. This program integrated education is regulated in the Decree of the Education and Culture Minister No. 002 / U / 1986 about the implementation of integrated education in Indonesia.

In 2004 at Bandung, a declaration was implemented which contained: 1) guaranteeing every disabilities child and other children with special needs to have access opportunities in all aspects of life, both in the education, health, social, welfare, security and other sectors so that they become generation reliably: 2) ensure that every disabilities child and other children with special needs as dignified individuals, to get humane treatment, quality education and accordance with the potential and needs of society, without discriminatory treatment that is detrimental for the life existence, like 
physical, psychological, economic, sociological, legal, political and cultural; 3) administer and develop inclusive education management supported by synergistic and productive cooperation between the government, educational institutions, related institutions, business and industry, parents and the community.

The declaration of inclusive education has also been implemented in North Sumatra Province as an effort to support the educational service administration for children with special needs. This declaration was implemented on 16 December 2015 at Medan, with the theme "Declaration of North Sumatra Province as administrator of Inclusive Education". This activity is carried out to implement the Education Regulation Ministry No. 70 of 2009, that each region is obliged to implement an inclusive education program that is evenly distributed in its territory, including North Sumatra Province.

The efforts made by the local government of North Sumatra Province to implement Permendiknas No. 70 of 2009 through the education office, the North Sumatera governor' decree No. 188.44 / 514 / KPTS / 2015 about the Inclusive Education Working Group of North Sumatra Province was issued. The purpose of establishing this inclusive education working group is to optimize education services for children with special needs by conducting socialization activities or campaigns to schools, parents and non-governmental organizations that focus on inclusive education providing.

Regarding the implementation of inclusive education in North Sumatra, the provincial government has also carried out socialization activities carried out by the inclusive education working group in the form of a national seminar on the culture of inclusive education in Indonesia. This activity aims: 1) to provide information for society, stakeholders and education stakeholders about the importance of inclusive education; 2) preparing strategic steps that might be taken to create an inclusive education culture in North Sumatra.

However, these efforts have not been able to optimize services in the administration of inclusive education in schools that are not classified as special education schools (SLB). Application of Permendiknas No. 70 of 2009, aims to provide equal opportunities for $\mathrm{ABK}$ with other students in the regular schools of North Sumatra. This lack of optimism occurs due to the lack of human resource capacity, funding, facilities and infrastructure as well as programs that can support the education inclusive implementation in regular schools.

\section{Literature Review}

Public policy has been carried out in an effort to fix the bureaucracy. Bureaucracy is identical with the procedure twisted, there is no certainty of time, expensive fees, and attitude of the officers who are not friendly to the community [1]. Public policy is a series of decisions that contain moral consequences in which there is an attachment to the interests of the society and an attachment to the homeland or the place where the person concerned is located. And this should be reflected in the behavior of the apparatus as the organizer, and there is interaction between the rulers and the people. Thus, the responsibility of a public administrator includes bureaucratic accountability, legal responsibility, professional responsibility, political responsibility and religious responsibility [2].

Public policy in an organizational context is a real instrument that describes the real relationship between government and society [3]. Meanwhile, public policy in a political context is top-down in the decision-making process for the sake of the group [4]. This is one of the factors that makes the policy no longer public, despite its wide implementation. Political processes can determine the form of governance as a tangible manifestation in public administration.

Dwiyanto states that when a service is declared a service guaranteed by the state, the state is obliged to provide it. This statement is intended as one of the main reasons for realizing a just and prosperous public service, because the opportunity to get education for $\mathrm{ABK}$ is not easy to obtain due to the different conditions [5].

The face of the bureaucracy in general in such a bad country is inevitably reflected in the education bureaucracy. The education bureaucracy as an inseparable part of the government bureaucracy in general is also affected by bureaucratic greed. The existence of such educational bureaucracies is more destructive than building education. The existence of education offices from the district to the central level undermines more than contributes to the development of education [6].

The public policy implementation as one of the dimensions is in the public policy process, which also determines whether a policy is in touch with the interests and can be accepted by the public. In this case, it can be emphasized that in the planning stage or policy formulation, it is possible to do the best possible, but if in the implementation stage, Standard Operating Procedures (SOPs) are not considered, then what is expected from a policy product. In the end, it is confirmed that the policy evaluation stage will result an assessment that the formulation and implementation of policies are not in line; that the policy implementation was not as expected; even the policy product can be a stumbling block for policymakers themselves [7].

The policy implementation is a stage of decision-making, such as articles of a legislative law, executive regulation, court decisions or regulatory standards and the consequences of policies for society that affect several aspects of their life. Although a policy is taken appropriately, the possibility of failure can still occur if the implementation process is not correct. Even if a reliable policy is implemented poorly and not optimally, it will fail to achieve the goals set by the makers. This suggests that policy implementation in substance is the right way to implement in order that a good policy can achieve the goals set by policy makers [7].

According to Donnelly and Watkins, inclusive education policies are changes made by every country around the world 
[8]. The goal is to develop inclusive education equally so that citizens who really need this education service can also improve their welfare through talent development. Meanwhile, according to Crawson and Brandes, the application of inclusive education in regular classes is to predict anxiety for each member of society who is a participant in providing education for children with special needs. The need for contact action between normal children and children with special needs oriented towards social domination, economic conservatism [9].

Based on their views, the theory of policy implementation is important to implement. Many experts have formulated policy implementation theory. Their views become a framework for researchers to see this theme. Therefore, the researcher choose to use the theory of George Edwards III in this research. According to Edwards III "Public Policy is what the governments say and do, or do not do it". In fact, the policy is a series of goals and objectives of government programs, whether they are carried out or not. Meanwhile, Carl Friedrich said that "Policy is an action that leads to the goals proposed by a person, group or government in a certain environment in connection with certain obstacles while looking for opportunities to achieve goals or achieve desired goals" [7].

According to Edward III's view, policy implementation is influenced by four variables [7]: Communication is the successful implementation of policies, requires in order that the implementers know what to do, where the goals and objectives of the policy must be transmitted to the target group (target group), thereby it will reduce implementation distortions.

Resources, although the content of police has been communicated clearly and consistently, but if the implementor lacks the resources to implement it, the implementation will not be effective. These resources can be in the form of human resources, for example the competence of implementers and financial resources.

Disposition, is the character and characteristics possessed by the implementor, such as commitment, honesty, democratic nature. If the implementor has a good disposition, then the implementor can carry out policies properly as desired by policy makers. When implementers have a different attitude or perspective from policy makers, the policy implementation process will also be ineffective.

Bureaucratic Structure, the organizational structure in charge of implementing policies has a significant influence on policy implementation. Aspects of the organizational structure are the Standard Operating Procedure (SOP) and fragmentation. Organizational structures that are too long will tend to weaken supervision and cause red-tape, namely complicated and complex bureaucratic procedures, which make organizational activities inflexible.

\section{Research Methods}

This research type is descriptive. This study uses a qualitative approach that aims to describe and analyze phenomena related to public services in the implementation of inclusive education at regular schools in North Sumatra Province. The qualitative approach implies a description of the data using words and lines of sentences. This is in accordance with the opinion of Bogdan and Taylor that qualitative methodology is a research procedure that produces descriptive data in the form of written or spoken words from people and observable behavior [10].

A qualitative approach is used to understand the reality deeply about dynamics of inclusive education in North Sumatra. According to Creswell, qualitative research focuses more on the process, meaning, understanding of experience, and partisan subjective appreciation. In addition, qualitative research is also more interested in meaning, namely partisan efforts to appreciate experiences and express their life. Qualitative research is less concerned about numbers (quantification), but tends to interpretation and accept its subjectivity to situations [11].

\section{Inclusive Education in North Sumatra}

Having a clear understanding of inclusive education is essential to the principles and values that underlie that understanding, the results can be very different. If inclusive education is defined narrowly, or based on the assumption of "children as the problem" and if then that definition is used to develop or monitor its practice, then inclusive education will fail or be unsustainable. The inclusive education definition also continues to develop in line with the deeper reflection of people on existing practices. In variouse things, The main concept and assumption that underlies inclusive education contradicts with the concepts and assumptions that underlying special education [12].

Efforts to provide this inclusive education service must be able to provide the rights of children with special needs to receive proper education and develop their intellectual and talent potential as regulated in law. Not only the government must play an important role, but also the parents of the children with special needs so that coordinated cooperation is established in implementing inclusive education in regular schools. Moreover, in Indonesia the number of children with special needs in 2017 reached 1.6 million children who really need optimal educational services in developing their potential. Meanwhile, there are still 268 thousand regular schools that can provide inclusive education. In 2010 there were $12 \%$ of people with disabilities of the world's population or around 650 million people with disabilities, where nearly $25 \%$ of that number or around 163 million people were school-age children [13].

The designated SLB is expected to be a supporter and companion for the implementation of inclusive education in regular schools so that children with special needs who are students in the environment have the same opportunity as other students to obtain optimal educational services [14], explains that the implementation of inclusive education really requires the role of the government, because inclusive education is an education service system based on the 
principle of upholding the main rights of children, namely education and the right to learn based on where they live.

The implementation of inclusive education requires a high level of responsiveness from the government in implementing inclusive education services. In this study, it describes the sensitivity and ability of the government in the implementation of inclusive education in the perspective of new public services [15].

The implementation of inclusive education in Sidoarjo is not running as expected in accordance with applicable policies. This inclusive education policy is implemented by forming an inclusive working group as a coordinator in the implementation of inclusive education in Sidoarjo. This working group is also assisted by special companion teachers (GPK) to provide inclusive education for children with special needs (ABK). However, this activity also could not be carried out properly due to the lack of facilities and infrastructure to support the implementation of inclusive education [16].

The general condition of special education in North Sumatra, inclusive education is a radical effort to looking at the education system with the basic assumption that everyone has the right to education. Inclusive education is a form of education that unites students with special needs and normal students to learn in general [16]. Inclusive education provides a pathway to give equal opportunities for students with special needs and ensure students to get education with appropriate curricula, learning strategies, and relationships patterns in the community [17].

The administration of inclusive education in general supports the social model and is intended to promote inclusion in all aspects of life [18]. This provides opportunities for students special needs, low economy and remote locations to get education in special schools such as Special Education Schools (SLB).

By regulation, inclusive education is contained in several government documents. First, inclusive education is stipulated in the Law of the Indonesia Republic No. 20 of 2003 about the National Education System in providing education for students with special needs. Second, Permendiknas No. 70 of 2009 concerning inclusive education which defines inclusive education as an education delivery system that provides opportunities for all students who have disabilities and have the potential for intelligence or special talents to participate in education or learning in an educational environment together with students in general.

The basic regulation is the stipulation of basic education rights for students with special needs in Article 31 Paragraph (1) of 1945 which reads "Every citizen has the right to education". All of these regulations cover and underlie the inclusive education applied in Indonesia. To achieve educational goals where inclusion becomes an educational practice, that needs an understanding of learning in schools. Teachers need to understand the social function of inclusive education by indicating that normal students learn to accept and understand other students who are different, which can be integrated into learning [19]. Even more so studies show that less than $25 \%$ of teachers have knowledge about inclusive classes for students with special needs, so there is an inability to accommodate student success [20].

In general, schools for students with special needs (ABK) are located in the provincial capital or district / city, so that ABK students who live in rural areas, is difficult to get education rights because of economic limitations and the remote location. Therefore, the inclusive education organized by the government really helps students with special needs to enjoy their education because public schools can accept them just like students in general.

Therefore, in 2015 North Sumatra declared itself as the province of inclusive education in Indonesia with approximately 633 schools are ready to administer inclusive education. Medan City is the capital of North Sumatra Province which was given the opportunity by the government to administer inclusive education which began with the preparation of guidelines for the administration of inclusive schools, socialization to various related components and simultaneous initiation of inclusive schools in various subdistricts in Medan City. Every schools in the districts or cities in North Sumatra accept special needs students to attend regular schools. The Central Bureau of Statistics recorded that there were 285,982 students with special needs, out of $2,859,824$ school age students in North Sumatra. This figure refers to the UN assumption that at least 10 percent of school age students total (5-14 years) are people with special needs. They are who can access education only 0.00018 percent to elementary schools (SD) and 0.00012 percent to junior high schools (SMP) [13].

The inclusive education is hoped in order that can be an effort to increase participation of student with special needs in school and to improve quality of inclusive education [21]. Inclusive education has traditionally been associated with students with special needs. Furthermore, explains that students are an important component in the implementation of inclusive education [22].

There are still many students with special needs who have not received education. This condition is due to various obstacles one of the community social conditions [21]. The symbols used by schools to classify the types of students with special needs are presented. Related to this classification, explain that teachers in public schools are more accepting of students with mild categories (visual and auditory) and different attitudes if it related with deaf students and mute students [23].

Law No. 20 of 2003 about the National Education System asserts that education is carried out through three channels, namely: formal education, non-formal education, and informal education. Formal education is carried out in schools, non-formal education is carried out in the community, and informal education is mainly carried out in the family. Therefore, non-formal and informal education is often associated as an education outside the school system or non-formal education. Apart from some differences in views that exist among the community (especially academics), it can be understood if the previous law, namely the National 
Education System Law No. 2 / 1989 emphasizes that national education is carried out through the school and non-formal education. In line with that, within the Department/Ministry of National Education, in the organizational structure of Ministry / Department is also a change in nomenclature from the Directorate General of External Education to be the Directorate General of Non-Formal and Informal Education.

As previously explained that the basic regulation related to inclusive education in Indonesia, it is Permendiknas No. 70 of 2009. Responding to this regulation, various regions have various responses. This is like what happened in Kediri, through Kediri Mayor Regulation No. 19/2012, which is an amendment to Kediri Mayor Regulation No. 27/2011, concerning Guidelines for Student Admission Implementation. Minor from the Mayor's Regulation is the guideline for implementing Inclusive Schools in Kediri. There are 8 SDN and 3 SMPN that will accept inclusive pathway students. explained in her research that among the 8 inclusive elementary schools above, only $1 \mathrm{SDN}$ is eligible to provide inclusive education (based on national education standards), while the others can't enter the category yet. This is due to common problems experienced by inclusive schools [16].

Conditions in Yogyakarta with the Yogyakarta Special Region Governor Regulation No. 21 of 2013, followed by the Decree of the Head of the Yogyakarta City Service No. 188/661 which was stipulated on 12 June 2014, there are 57 schools registered as administrators of inclusive schools, the 2016 Education Administering Madrasah Decree, which includes MAN of Maguwohardjo, MTSN of Sumbergiri, and MI of YAPI engineering school. In the East Java region, there is the Governor of East Java Regulation No. 6 of 2011 concerning the implementation of inclusive education, legalized January 25, 2011, one of which is MI of AlHidayah, which is located on J1. Margorejo Masjid No. 3-E Wonocolo Surabaya [16]. From several examples of regions that implement inclusive education based on Permendiknas No. 70 of 2009, they are still constrained by technical problems which cause difficult to implement the inclusive education in the regions. The obstacles that are often experienced are school standardization, school readiness, and government budgets in inclusive education.

The inclusive education case in North Sumatra is also the same problem. After the declaration of inclusive education in North Sumatra which was held at Merdeka Field in 2015, it appointed 3 high schools as pilot projects on inclusive education at the SMA / MA level. The three schools are SMA of Cahaya Medan, SMKN 10 of Medan and SMA of Methodist Medan. The interesting thing about the condition in North Sumatra that the regulations issued by the Provincial Government are still the Decree of the Governor of North Sumatra No. 188.44 / 514 / KPTS / 2015 concerning the Inclusive Education Working Group of North Sumatra Province. This is certainly different from other provisions that have issued Governor Regulations of inclusive education.

The decree issued as a form of responsiveness to
Permendiknas No. 70 of 2009 is a must, but the seriousness of the provincial government about regulation is the issuance of derivative regulations or a response to regulations which published nationally related to inclusive education. This is what isn't seen in North Sumatra Province. After the big declaration of inclusive education in 2015, there has not been found regulation yet on inclusive education in North Sumatra. However, in relation to inclusive education, the three schools designated as providers of Inclusive education for SMA/Ma level still execute the rules and accept ABK in schools. This condition is certainly interesting in terms of regulations and implementation carried out by schools in operations, because the only regulations from Permendiknas No, 70 of 2009 and the Decree of the Governor of North Sumatra Number 188.44 / 514 / KPTS / 2015 which is the reference.

\section{Reflecting on Permendiknas No. 70 of 2009}

Regarding inclusive education services in North Sumatra Province, especially that carry out inclusive education, it also give a unique picture, the implementation mechanism and the role of special education schools that do not work In the end are difficult to provide space for these services. This is more interesting when this discussed based on Permendiknas No. 70 of 2009. The condition of inclusive education in North Sumatra is on the worrying side of several problems, namely:

Inclusive education does not have regulations at the local level that can reinforce it in North Sumatra.

The indirectly change of leadership changes the regional strategic plan.

Assistance and support that never runs.

The division where Inclusive education is located in the North Sumatra Education Office is inadequate.

These four urgent problems are strong reasons for how inclusive education in North Sumatra has not been implemented since the first declaration in 2015. The first problem is that regulations at the provincial level never come out. This has become a main problem of implementation because the budgeting never existed. The main reference for regular schools in implementing inclusive education is Permendikbud no. 70 of 2009. Even though in some of the articles in the rule still needs to be re-translated. As in article two contains about providing the widest possible opportunity for all students who have physical, emotional, mental, and social disabilities, or potential for intelligence/ special talents to get quality education according to their needs and abilities; realizing the provision of education that respects diversity, and do not do discriminatory for all students. The Article two requires an explanation about how to provide quality education for children with special needs without causing discrimination. This metter will explain what is meant as non-discriminatory in regional regulation. The fact is that in North Sumatra never has regulation, so that the schools which organize inclunsive education translates itself what is 
meant discrimination, such as do not bully and equalize their rights with other normal students. In fact, this discriminatory element is much broader and needs a reference to explain it.

The article 4 explains that district / city governments appoint at least 1 (one) elementary school, and 1 (one) junior high school in each sub-district and 1 (one) secondary education unit to provide inclusive education which have to accept students. Referring to this article, inclusive education has appointed 3 middle-level schools to implement it in North Sumatra, namely SMKN 10 Medan, SMA of Cahaya Medan and SMA of Methodist Medan. The Schools have to provide quotas for children with special needs to be accepted at the school. The response related to article 4 ends here and it is the only rule applied from a series of rules that set out in Permendikbud no. 70 of 2009. However, the following articles are not really implemented. The same problem again is that local level regulations do not exist to support and explain in more detail about inclusive education.

The second problem is the change of leadership which can indirectly change the strategic direction of policy. This is related to the stability that occurred in North Sumatra in the period 2015-2020 which was full of political intrigue because leaders both at the provincial and regional levels were caught in corruption cases. Indeed, this does not directly change the direction of policy, it is just that the leaders who keep changing finally will drown strategic policies on inclusive education. This was also reinforced by the retirement of the head of the Education Office of North Sumatra, who handled inclusive issues in 2015. After retirement this program is not directly inherited so that the implementation stage at the lower level is not visible.

The third problem is that budget assistance and support is not running. This is an effect of the absence of regulations at the local level whereas the mandate in article 4 have been clear how local governments appoint several schools to carry out inclusive education, however this does not work as stated in article 6 where the district / city government guarantees the implementation of inclusive education according to students needs. The district / city government guarantees the availability of inclusive education resources at the designated education units. The government and provincial governments help provide inclusive education resources. Based on this article, the local government, both at the district, city and provincial levels, really guarantees the availability of resources, both training for regular teachers, and taking assistance from special education schools to support staff in implementing inclusive education in North Sumatra. This did not work so that the school only carried out normal educational procedures even though they still accepted children with special needs at school. This condition indirectly gives extra difficulties to children with special needs to receive education in the same way as other normal children.

The fourth problem is the inadequacy of the division responsible for inclusive education in North Sumatra. This is indirectly contradicting Article 12, namely the Government, provincial governments and district / city governments carry out guidance and supervision of inclusive education in accordance with their authorities. In the context of North Sumatra, both coaching and supervision have not been carried out since 2015, this is more due to the absence of a special division that gets at with inclusive issues. In the North Sumatra Education Office, the sector that gets at inclusion issues is the special education sector which concentrates on education for children with special needs in special education schools. In other words, this division is more focused on coaching and supervising the education process at special education schools in North Sumatra. Meanwhile, inclusive education which subject is the same as SLB is considered to have a slice, therefore the responsibility for the implementation of inclusive education in North Sumatra is handled by this division. However, the reality of this division does not focus on inclusive education in the field because inclusive education takes place in regular schools which are the authorities of the high school development and vocational high school sector. This bureaucratic problem is what become an obstacle how assistance for special education school and budget for inclusive school operations never came out.

\section{Conclusions and Suggestions}

The conclusion of this study is: The administration mechanism of inclusive education for children with special needs in regular schools in North Sumatra is not going well. This is more due to the inadequate communication between the school and the North Sumatra Education Office about how to make concrete steps in the administration of inclusive education in North Sumatra.

The role of special education school administrator who are accompanying regular schools in providing inclusive education in North Sumatra Province has never been carried out. This is because communication between the North Sumatra Education Office, regular schools of administrator inclusive education and special education schools as support staff has never been carried out. Inclusive education services in regular schools in North Sumatra Province which implement the policy of inclusive education that reflected in Permendiknas No. 70 of 2009, are not going well. This can be seen from regulations at the provincial and district levels in North Sumatra which never existed as a translation of Permendikbud No. 70 of 2009 concerning Inclusive Education.

Based on the conclusions above, there are recommendations from the results of this study that can be taken by policy makers and all stakeholders of Inclusive Education in North Sumatra, namely:

To increase the effectiveness of the implementation of inclusive education in North Sumatra, especially in operations so it is necessary to have regulations at the provincial level as a form of translation from Permendikbud No. 70 of 2009.

To maintain the quality of inclusive education in Sumatra, an assessment of implementation needs to be integrated 
where is schools that provide inclusive education, the North Sumatra Education Office and several special education schools in North Sumatra sit together to formulate strategic steps that must be taken.

An additional division is needed that specifically regulates inclusive education in the North Sumatra Education Office. Putting Inclusive education in one of the sectors such as senior high school guidance, vocational high school guidance and special education development is not the right solution which will instead provide space for overlapping decision making.

\section{References}

[1] Agus Sukristyanto, Sida Sonsri,. Sucipto, Nyoman Diah Utari Dewi, Zakariya), 2019. Public Policy in Improving Institutional Performance Eurasian Journal of Analytical Chemistry, OPEN ACCESS 201813 (6).

[2] Dunn, William N. 2019. Pengantar Analisis Kebijakan Publik (Terjemahan). Yogyakarta: Gadjah Mada University Press.

[3] Mulyadi, Deddy. 2019. Studi Kebijakan Publik dan Pelayanan Publik (Konsep dan Aplikasi Proses Kebijakan Publik Berbasis Analisis Bukti dan Untuk Pelayanan Publik) Edisi Revisi. Bandung: Alfabeta.

[4] Agustino, Leo. 2019. Dasar-dasar Kebijakan Publik (Edisi Revisi). Bandung: Alfabeta.

[5] Dwiyanto, Agus. 2020. Manajemen Pelayanan Publik: Peduli, Inklusif, dan Kolaboratif. Yogyakarta: Gadjah Mada University Press.

[6] Rohman, Arif. 2020. Kebijakan Pendidikan (Analisis Dinamika Formulasi dan Implementasi): Yogyakarta: Aswaja Pressindo.

[7] Kadji, Yulianto. 2019 N. D. Formulasi Dan Implementasi Kebijakan Publik. 2015: Universitas Negeri Gorontalo Press.

[8] Donnelly, Verity and Watkins, Amanda. 2020. Teacher Education For Inclusion In Europe. The Journal Prospect (2011) 41: 341-553: UNESCO IBE.

[9] Crawson, Michael and Brandes, Joyce. 2010. Predicting Community Opposition to Inclusion in Schools: The Role of Social Dominance, Contact, Intergroup Anxiety, and Economic Conservation. The Journal of Psychology, 2010, 144 (2), 121-144: Taylor and Francis Group, LLC.

[10] Maleong, Lexy. 2014. Metodologi Penelitian Kualitatif. Bandung: Remaja Rosdakarya.
[11] Creswell, J. W. 1998. Qualitative Inquiry and Research Design: Choosing among. Five Tradition. London: Sage Publications.

[12] Stubbs, Sue. 2002. Pendidikan Inklusif: Ketika Hanya Ada sedikit Sumber (terjemahan oleh).

[13] Rusmiyati, C. 2011. Kebutuhan Pelayanan Sosial Penyandang Cacat. Informasi Kajian Permasalahan Sosial dan Usaha Kesejahteraan Sosial. Jurnal Penelitian dan Pengembangan Kesejahteraan Sosial; 16 (1) 17-32.

[14] Kulish, Anatoliy N, et al. 2016. Implementation and Administrative Framework of the Inclusive Education in The Context of The Eurofean Integration Process. Journal of Advanced Research in Law and Economics, Volume VII Issue 6 (20) Fall 2016: Asers Publishing.

[15] Nurani, Apdita Suci, dkk. 2015. Responsivitas Pemerintah Dalam Penyelenggaraan Pendidikan Inklusif dalam Perspektif New Public Service. Jurnal Wacana Volume 18 Nomor 4 TAhun 2015, ISSN 1411-0199 E-ISSN 2338-1884.

[16] Sulistyadi, Hery, Kurnia. 2014. Implementasi Kebijakan Penyelenggaraan Layanan Pendidikan Inklusif di Kabupaten Sidoarjo. Jurnal Kebijakan dan Manajemen Publik Volume 2 Nomor 1 Januari 2014, ISSN 2303-341 X Universitas Airlangga.

[17] Devy, P. I. 2017. Impelementasi Kebijakan Pendidikan Inklusif Untuk ABK di Surabaya. Jurnal Dimensi Pendidikan dan Pembelajaran. (Online), Jilid 5, No. 1.

[18] Priyadarshini, S. Saradha; Thangarajathi, S. 2016. Effect of Selected Variables on Regular School Teachers Attitude towards Inclusive Education. Jurnal on Educational Psychology, v 10 n 3 p 28-38 Nov 2016-Jan 2017.

[19] Fernández, M. T. 2017. Attitudes toward Inclusive Education and Practical Consequences in Final Year Students of Education Degrees. Procedia - Social and Behavioral Sciences.

[20] Hwang, Y.-S., \& Evans, D. (2011). Attitudes towards inclusion: gaps between belief and practice. International Journal of Special Education, 26 (1).

[21] Abbas, F., \& Naz, T. 2016. Footstep towards Inclusive Education. Journal of Education and Practice Agustino, Leo. 2016. Dasar-dasar Kebijakan Publik (Edisi Revisi). Bandung: Alfabeta.

[22] Ilahi, Takdir, Mohammad. 2013. Pendidikan Inklusif (Konsep dan Aplikasi). Yogyakarta: Arruz Media.

[23] Prastiyono. 2013. Implementasi Kebijakan Pendidikan Inklusif (Studi di Sekolah Galuh. 